\title{
БОТАНИКА
}

УДК 581.524.4 (571.1)

doi: $10.17223 / 19988591 / 33 / 1$

\section{Н.В. Ветлужских}

Центральный Сибирский ботанический сад СО РАН, г. Новосибирск, Россия

\section{Встречаемость древесных пород в лесных фитоценозах Западной Сибири по широтному градиенту}

\begin{abstract}
Исследовались географические закономерности изменения флористического состава лесных фитоценозов Западно-Сибирской равнины по широтному градиенту от 55 до $68^{\circ}$ с.ш. Проанализирован видовой состав лесных сообществ 13 широтных отрезков. Выявлен прочент встречаемости по описаниям девяти древесных видов растений. Впервые дана характеристика зональных лесных сообществ конкретных ииротных отрезков Западно-Сибирской равнины и определено, насколько относительная встречаемость лесообразуюших древесных видов отображает описанные границь зон и подзон.
\end{abstract}

Ключевые слова: встречаемость древесных видов; лесная растительность; широтные границы; зональные сообщества.

\section{Введение}

Значительная протяженность западно-сибирских лесов в долготном направлении определяет их дифференциацию в зонально-секторальном отношении, что обусловлено климатом, а также особенностями рельефа, геологического строения и историей освоения территории человеком. Своеобразие и самостоятельный тип зональности растительного покрова Западной Сибири отмечали многие исследователи [1-9], лесам как основному элементу растительности уделено особое внимание [10-18]. Региональное своеобразие лесных фитоценозов выражается в первую очередь в изменении флористического состава и структуры древесного и подчиненных ярусов.

В связи с тем, что при аэро- и космической съемке древесный ярус наиболее различим, ему уделяется особое внимание. Но проследить границы зон и подзон только по снимкам не представляется возможным, поэтому необходим поиск других маркеров.

Встречаемость вида - один из объективных способов характеристики роли вида в фитоценозе [19]. Изменение процента встречаемости видов по описаниям (относительная встречаемость вида) по географическому градиенту является наглядным показателем при характеристике пространственных закономерностей распространения растительности. 
Для выявления широтной специфики флористического состава лесных сообществ Западно-Сибирской равнины проведен анализ относительной встречаемости высших сосудистых растений (травы, кустарнички, кустарники) и определены растения, диагностирующие зональные лесные сообщества от 55 до $68^{\circ}$ с.ш. [20].

Популяции доминирующих растений в той или иной степени способны изменять или создавать фитосреду [21]. Древесные виды в лесной зоне являются сильными эдификаторами, их популяции формируют наиболее крупные и длительно существующие комплексы и влияют на все ярусы растительного сообщества, а также животное население и верхние горизонты почвы $[22,23]$.

Цель данной работы - охарактеризовать зональные лесные сообщества конкретных широтных отрезков Западно-Сибирской равнины и определить, насколько относительная встречаемость лесообразующих древесных видов отображает описанные границы зон и подзон.

\section{Материалы и методики исследования}

Исследования проводились в центральной части Западно-Сибирской равнины в субмеридиальном направлении с 55 до $68^{\circ}$ с.ш. на территории Новосибирской, Омской, Томской и Тюменской областей (Ханты-Мансийский и Ямало-Ненецкий автономные округа).

Согласно зонально-провинциальному делению растительного покрова Западно-Сибирской равнины обследованная территория приходится на ОбьИртышскую геоботаническую провинцию, здесь проходят границы двух геоботанических зон: степной с лесостепной подзоной, бореальной (таежной) с 5 подзонами: подтаежной, южно-, средне-, северо-таежной и подзоной редколесий (рис. 1) [6].

При выполнении описаний растительных сообществ использованы методики, являющиеся общепринятыми в геоботанике [24, 25].

Для каждого геоботанического описания точно определены координаты, что позволило привязать его к конкретной точке на карте или космическом снимке. Массив геоботанических данных насчитывает 838 описаний, сделанных сотрудниками лаборатории геосистемных исследований ЦСБС СО РАН в период с 2007 по 2012 г. Хранение и обработка материалов проводились в пакете «IBIS» [26].

Во время сбора полевого материала выбирались лесные фитоценозы дренированных местообитаний без явных следов антропогенной нагрузки на суглинистых субстратах. Проанализирован видовой состав лесных сообществ 13 широтных отрезков. Выявлен процент встречаемости по описаниям девяти древесных видов растений. Латинские названия высших сосудистых растений даны по сводке С.К. Черепанова [27], листостебельных мхов - по сводке «Список мхов Восточной Европы и Северной Азии» [28], лишайников - по «Определителю лишайников России» [29]. 


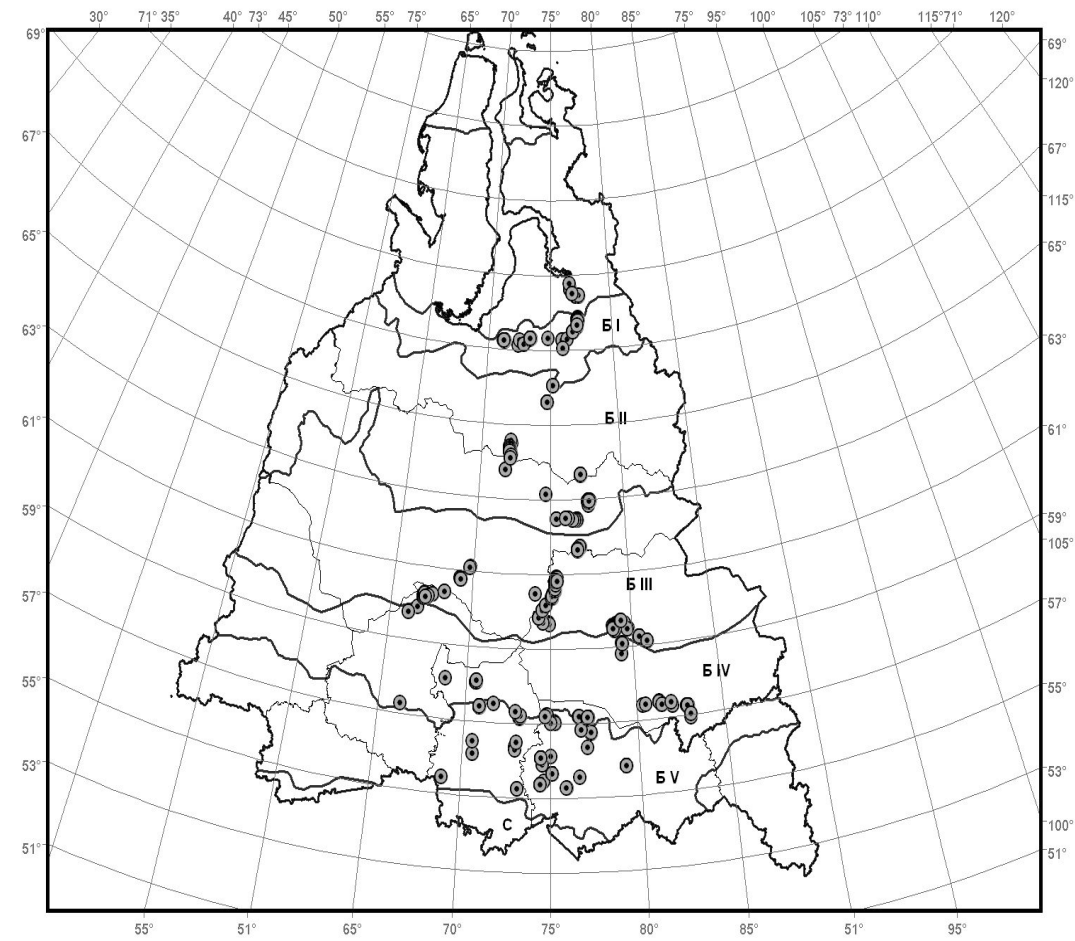

Рис. 1. Карта-схема Западной Сибири. Биоклиматические зоны [3]:

Б - бореальная (таежная): Б I - подзона редколесий (лесотундра), Б II - северная тайга, Б III - средняя тайга, Б IV - южная тайга, Б V - подтайга; С - степная зона (лесостепная подзона). Геоботанические описания обозначены серыми точками

[Fig. 1. Sketch map of West Siberia. Bioclimatic zones [3]: Б - Boreal (taiga): Б I - Woodland subzone (forest tundra), Б II - Northern taiga, Б III - Middle taiga, Б IV - Southern taiga, Б V - Subtaiga; C - Steppe zone (forest steppe subzone). Geobotanical descriptions are marked by grey dots]

\section{Результаты исследования и обсуждение}

Основные результаты работы демонстрирует таблица, в которой приводится встречаемость древесных растений (с учетом яруса) по широтному градиенту (таблица).

В лесах, описанных в широтном отрезке $55-56^{\circ}$ с.ш., древостой представлен Betula pendula Roth, B. pubescens Ehrh., Populus tremula L. высотой до 20 м. Диаметр деревьев иногда достигает 50 см, сомкнутость крон -0,4. Высота второго яруса редко более 14 м при сомкнутости крон 0,1 . Подрост березы и осины не активный до 1,5 м. Южнее 56-й параллели в древостое отсутствуют темнохвойные породы.

Кустарниковый ярус развит слабо (Salix bebbiana Sarg., S. caprea L., S. cinerea L.), и лишь Rosa acicularis Lindl. и R. majalis Herrm. иногда имеют до $20 \%$ проективного покрытия. 
Относительная встречаемость (\%) древесных пород лесных фитоценозов Западной Сибири по широтному градиенту ( $\left.{ }^{\circ} \mathrm{c} . ш.\right)$ [Relative occurrence (in \%) of tree species of forest phytocenoses in West Siberia along a latitudinal gradient $\left.\left({ }^{\circ} \mathrm{N}\right)\right]$

\begin{tabular}{|c|c|c|c|c|c|c|c|c|c|c|c|c|c|c|}
\hline $\begin{array}{c}\text { Вид } \\
\text { [Species] }\end{array}$ & 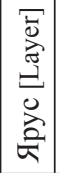 & $\begin{array}{l}\stackrel{0}{n} \\
i n \\
n\end{array}$ & $\begin{array}{l}\hat{n} \\
i n \\
i n\end{array}$ & $\frac{\infty}{i}$ & $\begin{array}{l}\infty \\
\infty \\
\infty \\
n\end{array}$ & $\begin{array}{l}8 \\
8 \\
1 \\
i\end{array}$ & $\begin{array}{l}\overline{0} \\
0 \\
0\end{array}$ & $\frac{\text { రె }}{\frac{1}{6}}$ & $\begin{array}{l}\text { b } \\
1 \\
\widetilde{\sigma}\end{array}$ & $\begin{array}{l}\mathbb{0} \\
1 \\
\hat{\sigma}\end{array}$ & $\begin{array}{l}n \\
f \\
\delta\end{array}$ & $\begin{array}{l}8 \\
0 \\
1 \\
6\end{array}$ & $\begin{array}{l}\hat{b} \\
b \\
0\end{array}$ & $\begin{array}{l}\infty \\
\frac{1}{6}\end{array}$ \\
\hline $\begin{array}{l}\text { Betula } \\
\text { pubescens }\end{array}$ & $\begin{array}{l}\text { a1 } \\
\text { a2 } \\
\text { a3 }\end{array}$ & $\begin{array}{c}29 \\
2 \\
5\end{array}$ & $\begin{array}{c}37 \\
4 \\
23\end{array}$ & $\begin{array}{c}20 \\
2 \\
6\end{array}$ & $\begin{array}{c}19 \\
1 \\
4\end{array}$ & $\begin{array}{l}70 \\
20 \\
42\end{array}$ & $\begin{array}{l}39 \\
28 \\
42\end{array}$ & $\begin{array}{l}81 \\
36 \\
78\end{array}$ & $\begin{array}{l}67 \\
29 \\
88\end{array}$ & $\begin{array}{l}73 \\
35 \\
61\end{array}$ & $\begin{array}{l}50 \\
21 \\
86\end{array}$ & $\begin{array}{c}24 \\
6 \\
10\end{array}$ & $\begin{array}{l}37 \\
37 \\
40\end{array}$ & $\begin{array}{c}24 \\
6 \\
15\end{array}$ \\
\hline Betula pendula & $\begin{array}{l}\text { a1 } \\
\text { a2 } \\
\text { a3 }\end{array}$ & $\begin{array}{c}76 \\
5 \\
8\end{array}$ & $\begin{array}{l}57 \\
14 \\
23\end{array}$ & $\begin{array}{l}89 \\
36 \\
56\end{array}$ & $\begin{array}{l}40 \\
15 \\
21\end{array}$ & 3 & & & & 12 & 7 & & 19 & 3 \\
\hline $\begin{array}{l}\text { Populus } \\
\text { tremula }\end{array}$ & $\begin{array}{l}\text { a1 } \\
\text { a2 } \\
\text { a3 }\end{array}$ & $\begin{array}{l}43 \\
11 \\
26\end{array}$ & $\begin{array}{l}90 \\
21 \\
57\end{array}$ & $\begin{array}{l}97 \\
31 \\
75\end{array}$ & $\begin{array}{c}60 \\
6 \\
42\end{array}$ & $\begin{array}{c}56 \\
5 \\
35\end{array}$ & $\begin{array}{c}96 \\
7 \\
55\end{array}$ & $\begin{array}{c}43 \\
7 \\
43\end{array}$ & $\begin{array}{l}46 \\
35\end{array}$ & $\begin{array}{l}24 \\
14 \\
25\end{array}$ & 7 & & & \\
\hline Picea obovata & $\begin{array}{l}\text { a1 } \\
\text { a2 } \\
\text { a3 }\end{array}$ & & $\begin{array}{c}3 \\
7 \\
18\end{array}$ & $\begin{array}{l}8 \\
8 \\
8\end{array}$ & $\begin{array}{l}64 \\
25 \\
64\end{array}$ & $\begin{array}{l}57 \\
45 \\
66\end{array}$ & $\begin{array}{l}46 \\
36 \\
62\end{array}$ & $\begin{array}{l}62 \\
29 \\
47\end{array}$ & $\begin{array}{l}58 \\
25 \\
27\end{array}$ & $\begin{array}{l}89 \\
33 \\
63\end{array}$ & $\begin{array}{l}86 \\
14 \\
64\end{array}$ & $\begin{array}{c}9 \\
6 \\
10\end{array}$ & $\begin{array}{c}12 \\
4 \\
16\end{array}$ & $\begin{array}{l}21 \\
18 \\
12\end{array}$ \\
\hline Abies sibirica & $\begin{array}{l}\text { a1 } \\
\text { a2 } \\
\text { a3 }\end{array}$ & & $\begin{array}{c}13 \\
2 \\
7 \\
\end{array}$ & $\begin{array}{c}3 \\
11 \\
8\end{array}$ & $\begin{array}{l}62 \\
28 \\
75\end{array}$ & $\begin{array}{l}45 \\
40 \\
83\end{array}$ & $\begin{array}{l}34 \\
23 \\
74\end{array}$ & $\begin{array}{l}22 \\
11 \\
46\end{array}$ & $\begin{array}{c}4 \\
2 \\
23 \\
\end{array}$ & $\begin{array}{c}4 \\
10 \\
\end{array}$ & & & & \\
\hline Pinus sibirica & $\begin{array}{l}\text { a1 } \\
\text { a2 } \\
\text { a3 }\end{array}$ & & $\begin{array}{c}3 \\
1 \\
17\end{array}$ & $\begin{array}{c}3 \\
19 \\
17\end{array}$ & $\begin{array}{c}78 \\
19 \\
4\end{array}$ & $\begin{array}{l}67 \\
45 \\
74\end{array}$ & $\begin{array}{l}68 \\
43 \\
18\end{array}$ & $\begin{array}{l}98 \\
44 \\
83\end{array}$ & $\begin{array}{l}71 \\
27 \\
79\end{array}$ & $\begin{array}{l}73 \\
29 \\
73\end{array}$ & $\begin{array}{c}100 \\
14 \\
93\end{array}$ & 3 & 5 & \\
\hline Pinus sylvestris & $\begin{array}{l}\text { a1 } \\
\text { a2 } \\
\text { a3 }\end{array}$ & & $\begin{array}{l}4 \\
1 \\
2\end{array}$ & $\begin{array}{l}6 \\
8\end{array}$ & $\begin{array}{c}28 \\
4 \\
7\end{array}$ & $\begin{array}{c}37 \\
10 \\
3\end{array}$ & $\begin{array}{l}50 \\
11 \\
18\end{array}$ & $\begin{array}{l}64 \\
18 \\
17\end{array}$ & $\begin{array}{l}69 \\
13 \\
21\end{array}$ & $\begin{array}{c}14 \\
2 \\
8\end{array}$ & 14 & & & \\
\hline Larix sibirica & $\begin{array}{l}\text { a1 } \\
\text { a2 } \\
\text { a3 }\end{array}$ & & & & & & & $\begin{array}{c}38 \\
3\end{array}$ & $\begin{array}{c}71 \\
8 \\
10\end{array}$ & $\begin{array}{l}97 \\
18 \\
16\end{array}$ & $\begin{array}{c}100 \\
14 \\
14\end{array}$ & $\begin{array}{c}100 \\
26 \\
39\end{array}$ & $\begin{array}{l}96 \\
38 \\
60\end{array}$ & $\begin{array}{l}91 \\
21 \\
56\end{array}$ \\
\hline Tilia cordata & $\begin{array}{l}\text { a1 } \\
\text { a2 } \\
\text { a3 }\end{array}$ & & & $\begin{array}{c}6 \\
17 \\
14\end{array}$ & & & & & & & & & & \\
\hline
\end{tabular}

Примечание. a1 - первый древесный ярус; а2 - второй древесный ярус; а3 - третий древесный ярус (подрост).

[Note. a1 - the first tree layer, a2 - the second tree layer, a3 - the third tree layer (undergrowth)]

Травостой высокий, до 1 м, проективное покрытие 90\%. Доминируют в травяном ярусе Rubus saxsatilis L., Brachypodium pinnatum (L.) Beauv., Iris ruthenica Ker-Gawl., Calamagrostis epigeios (L.) Roth. Эти растительные сообщества описаны как лесостепные березовые и осиновые леса [6]. В связи с этим можно считать, что северная граница распространения лесостепных мелколиственных лесов проходит примерно по $56^{\circ}$ с.ш.

В пределах с 56 по $57^{\circ}$ с.ш. первый древесный ярус описанных осиновых или березово-осиновых лесов имеет среднюю высоту 24 м, диаметр стволов 40 см и сомкнутость 0,6 . Единично в первом ярусе можно встретить хвой- 
ные породы (Pinus sylvestris L., Picea obovata Ledeb., Abies sibirica Ledeb.). Второй ярус сформирован березой и осиной и достигает высоты 10 м при сомкнутости 0,2 . Подрост березы и осины с примесью пихты, кедра, ели, сосны имеет высоту до 2 м и покрытие более $10 \%$.

Кустарниковый ярус обычно развит слабо, но представлен большим числом видов (Rubus idaeus L., Rosa acicularis, R. majalis, Padus avium Mill., Sorbus sibirica Hedl., Ribes nigrum L., R. spicatum Robson, Lonicera xylosteum L., Viburnum opulus L., Salix cinerea, Spiraea media Franz Schmidt, S. salicifolia L.). Только Caragana arborescens Lam. в некоторых сообществах может достигать 30\% покрытия.

Травяной покров высотой 1 м, проективное покрытие 70-90\%. Доминируют Aegopodium podagraria L., Carex macroura Meinsh., злаки Brachypodium pinnatum, Calamagrostis langsdorffii (Link) Trin., виды таежного разнотравья Aconitum septentrionale Koelle, Angelica sylvestris L. Такие леса описаны как подтаежные таежной зоны [6].

Можно предположить, что широтный отрезок с 57 по $58^{\circ}$ с.ш. - это зона распространения лесной растительности южно-таежной подзоны, поскольку севернее $57^{\circ}$ с.ш. меняется характер растительных сообществ. В этом широтном отрезке описаны березовые, осиновые, темнохвойно-мелколиственные леса. В первом ярусе - береза, осина, ель, сосна. Высота древостоя 24 м, диаметр стволов примерно $30 \mathrm{~cm}$, сомкнутость крон 0,5. Второй ярус развит хорошо и его высота в среднем 12 м, сомкнутость 0,2 ; чаще, чем на южном отрезке, встречаются пихта, кедр и липа. Те же породы хорошо возобновляются и формируют подрост до 2 м высотой при сомкнутости 0,2 (иногда 0,4 ).

Высота кустарникового яруса 1-3 м, сомкнутость почти всегда больше 0,1. Lonicera xylosteum и Spiraea media встречены только в пределах с 56 по $58^{\circ}$ с.ш.

В травяном ярусе доминируют Aegopodium podagraria (с высоким процентом встречаемости с 56 по $58^{\circ}$ с.ш.), Brachypodium pinnatum, Calamagrostis arundinacea, C. langsdorffii. Такие леса с кедром, липой во втором ярусе и участием в покрове зеленых мхов описаны в центральных районах тайги Западной Сибири как южно-таежные зонально-плакорные типы лесных сообществ [6].

Если особенной разницы по встречаемости древесных растений (исклю-

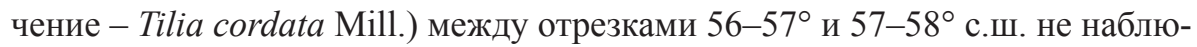
дается, что позволяет некоторым исследователям рассматривать их как гемибореальную подзону [13], то севернее 58-й параллели происходит смена доминантов древесного яруса с мелколиственных на хвойные деревья. Описанные сообщества в широтном отрезке с 58 по $61^{\circ}$ с.ш. представляют собой темнохвойные полидоминантные леса. Первый ярус 28 м высотой, сомкнутость 0,7 . Основные породы - пихта, кедр, ель. Лиственница в первом ярусе чаще встречается севернее $59^{\circ}$ с.ш. Диаметр стволов $30-50$ см. Второй ярус практически всегда выражен. Высота 14 м, сомкнутость 0,2-0,4. Подрост 
темнохвойных пород высотой до 1,5 м, иногда до 50\% покрытия.

Кустарниковый ярус не более 10\% покрытия. В 90\% описаний встречена Sorbus sibirica.

Доминантами в травяном ярусе являются Carex macroura, Oxalis acetosella L., Vaccinium myrtillus L., V. vitis-idaea L., Gymnocarpium dryopteris (L.) Newm., Rubus saxsatilis, Maianthemum bifolium (L.) F. W. Schmidt.

Моховой покров не сомкнут, проективное покрытие его 40-60\%. В его основе - Hylocomium splendens (Hedw) Bruch et al., Pleurozium schreberi (Brid.) Mitt, Ptilium crista-castrensis (Hedw.) De Not с куртинами Polytrichum commune L. в понижениях. Фитоценозы рассматриваемого широтного отрезка описаны как среднетаежные елово-кедровые леса [6].

Растительные сообщества, описанные с 61 по $65^{\circ}$ с.ш., это темнохвойные лишайниково-зеленомошно-кустарничковые леса. Первый ярус полидоминантный, почти всегда присутствуют кедр, ель, сосна и начинает встречаться лиственница. Высота его обычно 16 м (не более 22 м), сомкнутость крон 0,5. Если выражен второй ярус (примерно в 30\% описаний), то в первом - лиственница, а во втором - ель, кедр с примесью березы. Его высота 10-12 м, сомкнутость 0,2. Подрост до 2 м высотой, сомкнутость до 0,2.

Кустарниковый ярус практически не выражен. Единично, но часто встречаются Juniperus communis L., Rosa acicularis, Sorbus sibirica. В травяно-кустарничковом ярусе доминируют Carex globularis L., Ledum palustre L., Vaccinium myrtillus, $V$. uliginosum L., V. vitis-idaea. Проективное покрытие этого яруса достаточно велико, до 70\%. Мхи, где преобладают Hylocomium splendens, Pleurozium schreberi, Ptilium crista-castrensis, Polytrichum commune, и пятна лишайников (Cladonia Web. , Cladina Nyl., Cetraria Ach.) формируют сплошной покров. Такие леса описаны как северотаежные лиственничноеловые или лиственнично-елово-кедровые [6]. И если относительная встречаемость недревесных растений показала, что южная граница распространения этих лесов проходит между 60 и $61^{\circ}$ с.ш. [20], то встречаемость Larix sibirica хорошо маркирует границу между лесами средней и северной тайги по $61^{\circ}$ с.ш. (см. таблицу).

Лесные фитоценозы, описанные севернее $65^{\circ}$ с.ш., это лиственничные кустарничково-мохово-лишайниковые редколесья. Древостой редкий. Его средняя сомкнутость 0,2. В описанных лиственничных лесах обычна небольшая примесь ели и березы. В местах прошлых пожаров древостой имеет смешанный характер, иногда преобладает береза. В подлеске отмечена Betula nana L., покрытие может быть до 60\%.

Травяно-кустарничковый ярус разрежен (проективное покрытие не больше 30\%). Почти всегда в нем присутствуют Empetrum nigrum L., Ledum palustre, Vaccinium vitis-idaea. Мохово-лишайниковый покров практически сплошной. В нем преобладает Cladonia stellaris (Opiz) Pouzar et Vezda, в значительном количестве Cladonia arbuscula (Wallr.) Flot, C. rangiferina (L.) Wigg., Cetraria islandica (L.) ACH. , C. laevigata Rassad., из мхов-Pleurozium 
schreberi, Polytrichum juniperinum Hedw., P. coтmune. Такие леса описаны как лиственничные кустарничково-мохово-лишайниковые с субарктическими элементами редколесья [6]. После анализа встречаемости трав, кустарничков и кустарников выяснено, что ботанико-географический рубеж между северной тайгой и подзоной редколесий проходит между 64 и $65^{\circ}$ с.ш. [20], но тот факт, что Larix sibirica севернее $65^{\circ}$ с.ш. практически полностью сменяет темнохвойные породы, показывает, что южная граница распространения подзоны редколесий проходит по этой параллели.

\section{Выводы}

В результате анализа встречаемости по описаниям древесных видов зональных лесных сообществ Западно-Сибирской равнины по широтному градиенту с 55 до $68^{\circ}$ с.ш. выяснено:

- самый широкий диапазон встречаемости у Betula pubescens (с 55-й по 68-ю параллель);

- Betula pendula, заметно снижая встречаемость севернее $58^{\circ}$ с.ш., маркирует границу между южно- и среднетаежными лесами;

- северную границу распространения среднетаежных лесных сообществ показывает снижение процента встречаемости Populus tremula после $61^{\circ}$ с.ш.;

- севернее $56^{\circ}$ с.ш. начинают встречаться темнохвойные деревья, что демонстрирует начало распространения подтайги, а повышение процента их встречаемости севернее 58-й параллели показывает границу между южно- и среднетаежными лесами;

- Picea obovata дальше всех заходит на север и после 65-го градуса так же, как береза, является примесью в нарушенных лиственничных лесах;

- Abies sibirica, демонстрируя высокий процент встречаемости в первом ярусе с 58 по $61^{\circ}$ с.ш., может являться маркером лесных фитоценозов средней тайги;

- Pinus sibirica, практически не встречаясь после 65-й параллели, маркирует границу между северотаежными лесами и подзоной редколесий;

- Pinus sylvestris повышает процент встречаемости в зональных северотаежных лесах, это связано с тем, что в окружающих интрозональных сообществах, сформированных на супесчаной разновидности суглинистых почв, сосна является доминирующей древесной породой;

- по $61^{\circ}$ с.ш. проходит граница между лесами средней и северной тайги, что хорошо маркируется встречаемостью Larix sibirica, а то, что севернее $65^{\circ}$ с.ш. она сменяет темнохвойные породы, показывает границу между северной тайгой и подзоной редколесий;

- Tilia cordata, преимущественно во втором ярусе, встречена в сообществах только с 56 по $57^{\circ}$ с. ш. и может считаться маркером зональных южнотаежных лесов. 


\section{Литература}

1. Городков Б.Н. Опыт деления Западно-Сибирской низменности на ботаникогеографические области // Ежегодник Тобольского губернского музея. Тобольск, 1916. Вып. 27. С. 1-56.

2. Шумилова Л.В. Ботаническая география Сибири / под ред. Л.П. Сергиевской. Томск : Изд-во Том. ун-та, 1962. 439 с.

3. Лапшина Е.И. Геоботаническое картографирование таежной зоны Западной Сибири // Геоботаническое картографирование. Л. : Наука, 1973. С. 49-60.

4. Сочава В.Б. Растительный покров на тематических картах. Новосибирск : Наука, 1979. $190 \mathrm{c}$.

5. Сочава В.Б. Географические аспекты сибирской тайги / отв. ред. В.А. Снытко. Новосибирск : Наука, 1980. $256 \mathrm{c.}$

6. Ильина И.С., Лапшина Е.И., Лавренко Н.Н., Мельцер Е.А., Романова Е.А., Богоявлинский Б.А., Махно В.Д. Растительный покров Западно-Сибирской равнины / отв. ред. В.В. Воробьев, А.В. Белов. Новосибирск : Наука, 1985. 251 с.

7. Куминова А.В. Геоботанические исследования в Западной и Средней Сибири. Новосибирск : Изд-во СО АН СССР, 1987. 160 с.

8. Королюк А.Ю. Классификация территориальных единиц растительности равнинных территорий для целей создания геоинформационной системы «Растительность Сибири» // Геоботаническое картографирование 1997. СПб., 1999. С. 3-13.

9. Юрковская Т.К., Ильина И.С., Сафронова И.Н. Макроструктура растительного покрова России : анализ карты // Геоботаническое картографирование 2001-2002. СПб., 2002. C. $3-15$.

10. Толмачев А.И. К истории возникновения и развития темнохвойной тайги / отв. ред. А.П. Шенников. М. ; Л. : Изд-во АН СССР, 1954. 156 с.

11. Крылов Г.В. Леса Западной Сибири / под ред. Н.Е. Кабанова. М. : Изд-во АН СССР, $1961.255 \mathrm{c}$.

12. Горожанкина С.М., Константинов В.Д. География тайги Западной Сибири / отв. ред. В.Н. Смагин. Новосибирск : Наука, 1978. 190 с.

13. Hämet-Ahti L. The boreal zone and its biotic subdivision // Fennia. Helsinki, 1981. Vol. 159, № 1. P. 69-75.

14. Burton P.J., Messier C., Weetman G.F., Prepas E.E., Adamowicz W.L., Tittler R. The current state of boreal forestry and the drive for change // Towards sustainable management of the boreal forest. Ottawa, 2003. P. 1-40.

15. Ермаков Н.Б. Разнообразие бореальной растительности Северной Азии. Гемибореальные леса. Классификация и ординация / отв. ред. И.Ю. Коропачинский. Новосибирск : Изд-во СО РАН, 2003. 232 с.

16. Ермаков Н.Б., Лапшина Е.Д. Синтаксоны темнохвойных лесов из южной тайги Западно-Сибирской равнины // Вестник Новосибирского государственного университета. Серия: Биология, клинич. медицина. 2013. Т. ІІ, вып. 1. С. 75-82.

17. Лащинский Н.Н. Леса Западной Сибири - зонально-подзональная структура и синтаксономия // Растительность Восточной Европы и Северной Азии : материалы Международной научной конференции (Брянск, 28 сентября - 3 октября 2014 г.). Брянск, 2014. С. 87.

18. Лашинский Н.Н., Королюк А.Ю. Синтаксономия темнохвойных зональных лесов южной тайги Западно-Сибирской равнины и гумидных низкогорий Алтае-Саянской горной области // Растительность России. СПб., 2015. № 26. С. 85-107.

19. Миркин Б.М., Розенберг Г.С. Толковый словарь современной фитоценологии / отв. ред. Т.А. Работников. М. : Наука, 1983. 135 с. 
20. Ветлужских Н.В. Широтный анализ относительной встречаемости высших сосудистых растений в лесных фитоценозах Западной Сибири // Растительный мир Азиатской России. 2014. № 3(15). С. 72-80.

21. Быков Б.А. Проблема эдификаторов растительного покрова // Ботанический журнал. 1966. Т. 51, № 9. С. 1231-1243.

22. Карпачевский Л.О. Пестрота почвенного покрова в лесном биогеоценозе. М. : Изд-во МГУ, 1977. $312 \mathrm{c}$.

23. Носова Л.М., Гельиер Ю.Г., Холопова Л.Б., Раськова Н.В., Чернова Н.М., Бобров А.А., Матвеева В.М., Запрометова К.М., Сквориова К.М. Влияние смены древесной породы на биологические свойства дерново-позолистых почв // Биология почв Северной Европы / под ред. Д.А. Криволуцкого. М. : Наука, 1988. С. 154-184.

24. Юннатов А.А. Типы и содержание геоботанических исследований. Выбор пробных площадей и заложение экологических профилей // Полевая геоботаника / под общ. ред. Е.М Лавренко, А.А. Корчагина. М.; Л. : Наука, 1964. Т. 3. С. 9-36.

25. Ипатов В.С. Описание фитоценоза. Методические рекомендации. СПб. : СПб. гос. ун-т, 1998. 93 с.

26. Зверев А.А. Информационные технологии в исследованиях растительного покрова. Томск : ТМЛ-Пресс, 2007. 304 с.

27. Черепанов С.К. Сосудистые растения России и сопредельных государств / под ред. Г.С. Розенберга, С.В. Саксонова. СПб. : Мир и семья, 1995. 990 с.

28. Игнатов М.С., Афонина О.М., Игнатова Е.А. и др. Список мхов Восточной Европы и Северной Азии // Arctoa. 2006. Т. 15. С. 1-130.

29. Определитель лишайников России / под ред. Н.С. Голубковой. СПб. : Наука, 1996. Вып. 6. 202 с.

Поступила в редакиию 15.12.2015 г.; повторно 02.03.2016 г.; принята 10.03.2016 г.

Ветлужских Наталья Владимировна - канд. биол. наук, н.с. лаборатории геосистемных исследований Центрального Сибирского ботанического сада СО РАН (г. Новосибирск).

E-mail: dvetl@mail.ru

Vetluzhskikh NV. Occurrence of tree species in forest phytocenoses of West Siberia along a latitudinal gradient. Vestnik Tomskogo gosudarstvennogo universiteta. Biologiya - Tomsk State University Journal of Biology. 2016;1(33):6-17. doi: 10.17223/19988591/33/1 In Russian, English summary

\section{Natalia V. Vetluzhskikh}

Central Siberian Botanical Garden, Siberian Branch of the Russian Academy of Sciences, Novosibirsk, Russian Federation

\section{Occurrence of tree species in forest phytocenoses of West Siberia along a latitudinal gradient}

The aim of this work was to describe zonal forest communities of concrete latitudinal segments of the West-Siberian plain and define how the relative occurrence of forestforming tree species corresponds to the described boundaries of zones and subzones.

We studied geographical pattern changes of floristic composition of forest communities over the West-Siberian plain (from 55 to $68^{\circ}$ n.l.). Our research was conducted in the central part of West Siberia on the territories of Novosibirsk, Omsk, Tomsk and Tyumen oblasts. To collect field material, we selected forest phytocenoses of drained habitats without obvious signs of anthropogenic loading on loamy substrates, where sample plots were laid $(10 \times 10=100$ sq. m), on which we fixed the total 
vegetation projective cover, specified the height and the density of the tree layer and determined the species composition of the community and the projective cover of each species in percentage terms.

We analyzed 13 latitudinal sections of forest-forming trees and described the main characteristics of forest communities. Basing on descriptions of nine woody species we defined the percentage of occurrence. It was for the first time that the relative occurrence of forest-forming tree species and characteristics of forest communities were shown for particular latitudinal sections. It allowed us to define the limits of forest-steppe and forest zones of the West Siberian plain. It turned out that Betula pubescens has the widest section range of occurrence. Significantly reducing the occurrence north of $58^{\circ}$ n.l, Betula pendula marks the boundary between the southern and middle taiga forests. The northern boundary of the middle taiga forest communities occurrence shows a decline in the percentage of Populus tremula occurrence after $61^{\circ}$ n.l. North of $56^{\circ}$ n.l. there are coniferous trees, which prove the beginning of subtaiga distribution, and the increase in the percentage of their occurrence to the north of 58 parallel shows the boundary between the southern and middle taiga forests. Picea obovata is situated farthest to the north, and after the $65^{\circ}$, as well as the birch, is admixture in disturbed larch forests. Abies sibirica, demonstrating a high percentage of occurrence in the first layer from 58 to $61^{\circ}$ n.l. may be a marker of forest communities of the middle taiga. Pinus sibirica, rarely occurring after the 65 th parallel, marks the boundary between the north-taiga forests and woodland subzones. Pinus sylvestris increases the percentage of occurrence in zonal north-taiga forests. At $61^{\circ} \mathrm{n}$.l. is the boundary between forests of the northern and the middle taiga, which is well marked by Larix sibirica occurrence, and the fact that it replaces coniferous species to the north of $65^{\circ}$ n.l. of the parallel, shows the boundary between the northern taiga and woodland subzones.

The article contains 1 Figure, 1 Table, 29 References.

Key words: occurrence of tree species; forest vegetation; latitudinal limits; zonal community.

\section{References}

1. Gorodkov BN. Opyt deleniya Zapadno-Sibirskoy nizmennosti na botaniko-geograficheskie oblasti [Experience of dividing the West Siberian lowland into botanical and geographical areas]. Ezhegodnik Tobol'skogo Gubernskogo Muzeya - Year-book of Tobolsk provincial museum. 1916;27:1-56. In Russian

2. Shumilova LV. Botanicheskaya geografiya Sibiri [Botanical geography of Siberia]. Sergievskaya LP, editor. Tomsk: Tomsk State University Publ.; 1962. 439 p. In Russian

3. Lapshina EI. Geobotanical cartography in the taiga of West Siberia. Geobotanical mapping 1973. Sochava VB, Isachenko TI, editors. Leningrad: Nauka Publ.; 1973. pp. 49-60. In Russian

4. Sochava VB. Rastitel'nyy pokrov na tematicheskikh kartakh [Vegetative cover on thematic maps]. Novosibirsk: Nauka, Siberian Branch Publ.; 1979. 190 p. In Russian

5. Sochava VB. Geograficheskie aspekty sibirskoy taygi [Geographical aspects of the Siberian taiga]. Snytko VA, editor. Novosibirsk: Nauka, Siberian Branch Publ.; 1980. 256 p. In Russian

6. Il'ina IS, Lapshina EI, Lavrenko NN, Mel'tser EA, Romanova EA, Bogoyavlinskiy BA, Makhno VD. Rastitel'nyy pokrov Zapadno-Sibirskoy ravniny [Vegetative cover of the West Siberian plain]. Vorob'yev VV, Belov AV, editors. Novosibirsk: Nauka, Siberian Branch Publ.; 1985. 251 p. In Russian

7. Kuminova AV. Geobotanicheskie issledovaniya v Zapadnoy i Sredney Sibiri [Geobotanical studies in West and Central Siberia]. Novosibirsk: SB AS USSR Publ.; 1987. 160 p. In Russian 
8. Korolyuk AJu. Classification of the territorial vegetation units of plant territories with the aim of creating of the geographic information system "Vegetation of Siberia". Geobotanical mapping 1997. Yurkovskaya TK, Kholod SS, editors. St. Petersburg: Academy of Sciences of Russia Komarov Botanical Institute; 1999. pp. 3-13. In Russian

9. Yurkovskaya TK, Il'ina IS, Safronova IN. Macrostructure of vegetation cover in Russia: analysis of map. Geobotanical mapping 2001-2002. Yurkovskaya TK, Kholod SS, editors. Yurkovskaya TK, Kholod SS, editors. St. Petersburg: Academy of Sciences of Russia Komarov Botanical Institute; 2002. pp. 3-15. In Russian

10. Tolmachev AI. K istorii vozniknoveniya i razvitiya temnokhvoynoy taygi [On the history of taiga forest origin and development]. Shennikov AP, editor. Moscow, Leningrad: AS USSR Publ.; 1954. 156 p. In Russian

11. Krylov GV. Lesa Zapadnoy Sibiri [Forests of West Siberia]. Kabanov NE, editor. Moscow: AS USSR Publ.; 1961. 255 p. In Russian

12. Gorozhankina SM, Konstantinov VD. Geografiya taygi Zapadnoy Sibiri [Geography of the West Siberian taiga]. Smagin VN, editor. Novosibirsk: Nauka, Siberian Branch Publ.; 1978. 190 p. In Russian

13. Hämet-Ahti L. The boreal zone and its biotic subdivision. Fennia. 1978;159(1):69-75

14. Burton PJ, Messier C, Weetman GF, Prepas EE, Adamowicz WL, Tittler R. The current state of boreal forestry and the drive for change. In: Towards sustainable management of the boreal forest. Burton PJ, Messier C, Smith DW, Adamowicz WL, editors. Ottawa, Ontario, Canada: NRC Research Press: 2003. pp. 1-40.

15. Ermakov NB. Raznoobrazie boreal'noy rastitel'nosti Severnoy Azii. Gemiboreal'nye lesa. Klassifikatsiya i ordinatsiya [Diversity of boreal vegetation in Northern Asia. Hemiboreal forests. Classification and ordination]. Koropachinskiy IYu, editor. Novosibirsk: Siberian Branch of Russian Academy of Sciences Publ.; 2003. 232 p. In Russian

16. Ermakov NB, Lapshina ED. Syntaxa of dark-coniferous forests from south-boreal subzone of West Siberian plain. Vestnik Novosibirskogo gosudarstvennogo universiteta. Seriya: Biologiya, klinich. meditsina. 2013;11(1):75-82. In Russian, English Summary

17. Lashchinskiy NN. West Siberian forests - zonal structure and syntaxonomy. In: Rastitel'nost' Vostochnoy Evropy i Severnoy Azii. Materialy mezhdunarodnoy nauchnoy konferentsii [Vegetation of the East Europe and Northern Azia. Proc. of the Int. Sci. Conf. (Bryansk, Russia, 28 September - 3 October, 2014)]. Bryansk: Bryanskoe poligraficheskoe ob"edinenie Publ.; 2014. p. 87. In Russian

18. Lashchinskiy NN, Korolyuk AYu. Syntaxonomy of zonal dark-coniferous forests of the West Siberian of the southern taiga and the Altai-Sayan humid low-mountains. Rastitel 'nost' Rossii-Vegetation of Russia. 2015;26:85-107. In Russian, English Summary

19. Mirkin BM, Rozenberg GS. Tolkovyy slovar' sovremennoy fitotsenologii [Explanatory dictionary of modern phytocenology]. Rabotnikov TA, editor. Moscow: Nauka Publ.; 1983. $135 \mathrm{p}$.

20. Vetluzhskikh NV. Latitudinal analysis of the relative occurrence of higher vascular plants of the forest phytocenosis of Western Siberia. Rastitel'nyy mir Aziatskoy Rossii - Vegetation world of the Asian Russia. 2014;3(15):72-80. In Russian, English Summary

21. Bykov BA. Problema edifikatorov rastitel'nogo pokrova [Problem of vegetative cover edificators]. Botanicheskij zhurnal - Botanical Journal. 1966;51(9):1231-1315. In Russian

22. Karpachevskiy LO. Pestrota pochvennogo pokrova $v$ lesnom biogeotsenoze [Diversity of soil cover in a forest biogeocenosis]. Moscow: Moscow State University Publ.; 1977. 312 p. In Russian

23. Nosova LM, Gel'tser YuG, Kholopova LB, Ras'kova NV, Chernova NM, Bobrov AA, Matveeva VM, Zaprometova KM, Skvortsova KM. Vliyanie smeny drevesnoy porody na biologicheskie svoystva dernovo-pozolistykh pochv [Influence of tree species change on 
biological properties of sod-podzolic soils]. In: Biologiya pochv Severnoy Evropy [Biology of soils in Northern Europe]. Krivolutskiy DA, editor. Moscow: Nauka Publ.; 1988. pp. 154184.

24. Yunnatov AA. Tipy i soderzhanie geobotanicheskikh issledovaniy. Vybor probnykh ploshchadey i zalozhenie ekologicheskikh profiley [The types and scope of geobotanical investigations. The selection of sample areas and the construction of ecological profiles]. In: Polevaya geobotanika [Field geobotany]. Lavrenko EM, Korchagin AA, editors. Moscow, Leningrad: Nauka Publ.; 1964. Vol. 3. pp. 9-36. In Russian

25. Ipatov V.S. Opisanie fitotsenoza. Metodicheskie rekomendatsii [Description of phytocenosis. Methodical recommendations]. St. Petersburg: SPb State University Publ.; 1998. 93 p.

26. Zverev AA. Informatsionnye tekhnologii $\mathrm{v}$ issledovaniyakh rastitel'nogo pokrova [Information technologies in vegetative cover studies]. Tomsk: TML-Press Publ.; 2007. 304 p. In Russian

27. Cherepanov SK. Sosudistye rasteniya Rossii i sopredel'nykh gosudarstv [Vascular plants of Russia and adjacent states (the former USSR)]. Rozenberg GS, Saksonov SV, editors. St. Petersburg: Mir \& Sem'ya-95 Publ.; 1995. 991 p. In Russian

28. Ignatov MS, Afonina OM, Ignatova EA. et al. Check-list of mosses of East Europe and North Asia. Arctoa. 2006;15:1-130.

29. Opredelitel' lishaynikov Rossii [Keys to lichens of Russia]. Vol. 6. Golubkova NS, editor. St. Petersburg: Nauka Publ.; 1996. 202 p.

Received 15 December, 2015;

Revised 2 March 2016;

Accepted 10 March 2016

\section{Author info:}

Vetluzhskikh Natalia V, Cand. Sci. (Biol.), Researcher, Laboratory of Geosystem Research, Central Siberian Botanical Garden, Siberian Branch of the Russian Academy of Sciences, 101 Zolotodolinskaya Str., Novosibirsk 630090, Russian Federation.

E-mail: dvetl@mail.ru 